vancement, I attended 500 cases of midwifery in twenty three months-for nothing.

The profession owes you a large obliga. tion, it relies on your judgment, is convinced of your integrity, and therefore may be greatly infuenced by your advocacy : reconsider all the circumstances of the poor, and the condition of the profession; espe. ally as influenced by the WHra atroeity, the New Poor Law Amendment Act, a measure which, in the conception, gtamps its contrivers as scarcely better than idiots, exceeded in fatuity only by their nose-led and selfish approvers, set about inquiring whether halfa-crown a year was not better than nothing, as it would have been in my case; or, still better, than $5 \mathrm{~s}$. or $15 \mathrm{~s}$. extorted by low and oppressive psendo-judicial proceedings ; or higgling for sixpences in seven-shilling accounts current; or vending powders at $3 d$. per dozen, and bargaining about mixtures at "the low price of one shilling?" "Reform it altogether." Yours, \&c.

Delta.

\section{THE BRIDGWATER BOARD OF GUARDIANS AND THE MEDICAL OFFICERS.}

\section{To the Editor of The LANCET.}

SIR :--An advertisement having appeared in the Standard, and other papers, for medical practitioners to take charge of the Paupers of the Bridgwater Union, I shall be much obliged by your giving publicity to the following statement of facts for the information of the profession generally :-

The medical gentlemen who undertoook the charge of the poor, during the last year, having found that they were coxsiderable losers by their contracts, declined to renew them on the very low terms offered by the Board, but were willieg to accept the minimum average paid throughont the kingdom. This reasonable offer was rejected by a majority of twenty-four to nineteen; two unqualified men were then appointed to a distyict which one surgeon had taken charge of before, and a resolution was passed to advertise for four surgeons to undertake the care of the remaining districts which the Board had determined, at a former meeting, should be divided into seven, five active surgeons having been found to he an insufficient number to perform the duties re. quired. The medical officers have always been treated by the Guardians with marked disrespect. No representation from them, however impurtant, has ever received the slightest attention, not even a formal acknowledgment, and the Board, finding themselves unable to awe them into submission, or compel them to accept terms which were degrading to the profession, allow themselves to be influenced by resentment and vindictive feelings, and threaten to bring opponents into the neighbourhood. As soon as this disgraceful business is settled, the medical gentlemen intend to briug the whole affair before the public, and, in the meantime, I hope you will be so good as to insert this communication in an early Number. I am, Sir, your obedient servant,

J. Baruch ToOgood.

Bridgwater, July 3, 1837.

**We have been unavoidably compr lled to delay the publication of this letter.Eis. L.

\section{TERMS OF SCIENCE IN NATURAL HISTORY.}

PRESERVATION OF SKINS, \&C.

\section{To the Editor of THE LANCET.}

Sir:-I berewith enclose a letter transmitted to me by my friend Charles Waterton, Esq., of Walton-Hall, Yorkshire, on which any comments from me might be considered presumptuous, as it carries with it, most pointedly, its own justification. I cannot avoid remarking, however, that the researches of this student of nature appear, in my humble opinion, to be of intinitely more value than those of all the cabinet or eloset naturalists, with all their parade of ephemeral arrangements and affected nomenclature, their pedantry and rork with lexicons, murdering the Greek for the ma. nufactare of absurd and barbarous terms, and all this with the view of imposing an air of noveliy on worthless compilations. When such affected jargon'and mummery, misnamed science, shall have given place to truth and reason, then, doubtless, will be read with delight the graphic descriptions $\mathrm{MI}$. Waterton has given from careful observation amidst the deep and sombre retreats of the South American forests.

What this author has remarked on the habits of the American vulture (as well as of other animals) I know to be correct. The bird here mentioned is certainly guided to its food, not merely by the eye but by the sense of smell, as are most insects and many other animals. *

I can well say thus much of Mr. Waterton's labours, having, in South America, witness. ed his zeal and assiduity in acquiring a knowledge of animals in their native haunts. Such acquisitions form the genuine naturalist, and too often excite the envy of those who are less informed, and affect to condemn what is altogether beyond their reach. It is to be hoped that many rirtuosi will receive

* This appears to be, in some degree, anatomictlly corroborited, from a disscction of one of these birds, as tated in a paper read at a late meteing of the Zoological Society by Mr. Lesler, who observed a remarkable development of its olfactory organs. 
a salutary hint from the remarks of Mr. W., departed this life. If it be the case that and learn from thence that science (so termed) without common sense, is but idle jabber.

A justly celebrated Professor in the University of Northern Athens, who had unluckily joined in the hue and cry in praise of a modern Baron Munchausen, received, two years ago, from Mr. W., a severe rebuke, to which he has not thought proper to attempt a reply; indeed, the said Professor has shown good sense in a tacit acknowledgment of his error, and by omitting any further plaudits on the individual in question.

I would make one remark further, i. e., on the preservation of skins and other animal substances, a subject of no small importance to natural historians. I have often employed the alcoholic solution of corrosive sublimate, as recommended by $\mathrm{Mr}$. Waterton, since he gave me his recipe in 1812 , and always with perfect success, when duly prepared. I have also tried the arsenical soap, but with me it has proved useless. Arsenic, indeed, is a potent corrosive, or caustic, but scarcely possessed of any antiseptic or preservative property.* It is true that I had previously employed the sublimate in a compound powder from Ruckahn's recipe (see "Phil. Trans." 1770, and "Dr. Lettsom's Travellers' Companion") an expensive preparation, containing withal a quarter of a pound of musk. As to Sir James Snith's recommendation of the use of corrosive sublimate, it was, if I remember well, only against the depredations of insectson dried plants, and not as a preservative of animal substances. I am, Sir, your obedient servant,

London, July, 1837.

John Hancock.

* Should a non-corrosive antiseptic be wanted, the oxymuriate or chlorate of potash will be found to be one of the most effectual.

POST-MORTEM EXAMINATION OF THE DUCHESS OF ST. ALBANS.

\section{To the Editor of THE LanceT.}

SIR :-In the Morning Chronicle of this day, the following adrertisement appears, page 3 , col. 4 :- "The body of the late Duchess of St. Albans has undergone a post-mortem examination, which was performed by Mr. MAyo." Now, Sir, I ber to ask whether this is the truth. I have heard, accidentally, that another gentleman, a teacher of anatomy, was called in by Mr. Wardrop, the surgeon of the late Duchess, to examine the body, at the wish of his Grace, the Duke, and that that gentleman did perform the post-mortem examination, assisted by $\mathbf{M r}$. Mayo, who was invited to be present by he physician under whose care her Grace

Mr. Mayo was only a partner in the ne. cropsy, I beg to know how that gentleman, or whoever else wrote the advertisement (and a good guess may be made of the authorship), justifies the advertising of only one name on this occasion? With regard to the assistance of Mr. Mayo, I can say that it is not regarded in the profession as exactly the thing for a "pure," who is amongst the most determined sticklers for rank and surgical position, to be going abont taking fees, of either two or ten guineas, for opening dead bodies in private houses. I am, Sir, your obedient servant,

London, Thursday, Aug. 10th.

Andrew Machay.

THE QUEEN'S "MEDICAT. EST A BLISH MENT."

(From the London Gazelte, Aug. 8, 1837.)

Physicians in Ordinary.-James Clark, M.D.; Sir Henry Halford, Bart., M.D., G.C.H. ; William Frederic Chambers, M,D., K.C.H.

Sergeant Surgeons, - Sir Astley P. Cooper, Bart., G.C.H.; Sir Benjamin C. Brodie, Bart.; Robert Keate, Esq.

M.D.

Physician to the Household.-James Clark, Esq.

Apothecary to the Person.--John Nussey, Esq, and Edward Duke Moore, Esq., jointly.

A pothecary to the Household.-John Nus. sey, Esq., and Charles Craddock, Esq., jointly.

The Queen has also been pleased to ap. point-

Sir James M'Grigor, Bart., M.D. ; Henry Holland, M.D.; Peter Mere Latham, M.D.; Richard Bright, M.D.; and Neil Arnott, M.D., Physicians Extraordinary to $\mathrm{Her}$ Majesty.

Benjamin Travers, Esq.; Thomas Copeland, Esq.; William La wrence, Esq. ; Henry Earle, Esq.; and Richard Blagden, Esq., Surgeons Extraordinary to Her MIajesty.

Messrs. Merriman, of Kensington, A pathecaries Extraordinary to Her Majesty.

Charles Dumergue, Esq., Surgeon Dentist to Her Majesty.

Louis Durlacher, Esq., Surgenn Chiropodist to Her Mrjosty.

Mr. Squire, Chemist amd Druggist to IItr Majesty. 